\title{
DIURETICS EFFECT OF SALAK (Salacca zalacca) SEED EXTRACT TO KIDNEY HISTOPATHOLOGICAL STRUCTURE OF THE WISTAR MALE RATS (Rattus norvegicus)
}

\author{
Nur Aisyah Septiana, Rike Oktarianti, Asmoro Lelono \\ Universitas of Jember \\ rike.fmipa@unej.ac.id
}

\begin{abstract}
Salak seed are used as natural diuretics, it's contained secondary metabolites i.e alkaloids, flavonoids and tannins. Diuretics are compounds that can increase the rate of excretion of urine volume and increase the excretion of mineral salts in the urine. The study was to determine the diuretic effect of salak seed extract on the histopathological structure of the kidney. Salak seed extract was made by maceration method using $70 \%$ ethanol and then evaporated. Rats were divided into 4 treatment groups, negative control and 3 treatment groups with the administration of salak seed extract for 7 days orally at a dose of $0.28 \mathrm{~g} / \mathrm{kg}$ body weight, $0.56 \mathrm{~g} / \mathrm{kg}$ body weight and $1.12 \mathrm{~g} / \mathrm{kg}$ body weight. The Anova test result showed $p$ value was 0.647 ( $p>0,05$ ). This is indicated there was no significantly difference of all treatment. Thus, the doses variation of salak seed extract had no effect on the kidney histopathological structure, i.e it was not affect on glomerular diameter or did not cause atrophy of kidney glomerular. Thus the use of salak seeds as a natural diuretic is safe didn't effect to damage kidney so it can be used as a substitute for synthetic diuretics.
\end{abstract}

Keywords: diuretics effect, extract of salak seed, kidney histopatological, Rattus norwegicus

\section{INTRODUCTION}

Salak is a plant species in Arecaceae family (Cronquist, 1981). Salak is useful as an antioxidant, maintaining eye health, anti diabetic, reduce cholesterol, and anti diarrhea. According to Novita (2013), salak seeds can be used as drinks and diuretics. Salak seeds contain flavonoid and have function as diuretics that work by increasing the glomerular filtration rate (Jouad et al., 2001).

Diuretics are compounds can increase the rate of excretion of urine volume and increase the excretion of mineral salts in the urine (Guyton and Hall, 2006). Diuretics working by increasing the excretion of $\mathrm{Na}+$ $\mathrm{Cl}-$ or $\mathrm{HCO} 3-$ ions which are the main electrolytes in extracellular fluid and decreasing electrolyte reabsorption in the renal tubules (Siswandono, 2016). Saravanan et al. (2010), stated that diuretic compounds consist of saponins, terpenoids and flavonoids. Nurihardyanti et al. (2015), reported that the compounds that are diuretic in papaya seeds and salak seeds are alkaloids and flavonoids. Alkaloids are secondary metabolites that contain one nitrogen atom and are basic (Achmad, 1986). Alkaloid in salak seeds is diuretic by acting on the kidney tubules by increasing the excretion of $\mathrm{Na}+$ and Cl-. Increased excretion of $\mathrm{Na}+$ will increase in water excretion so that urine volume increases (Nessa et al., 2013).

The most used diuretic compounds by the public are synthetic diuretics (Tanu, 2009). Synthetic diuretics that are consumed in the long term and exceed the recommended dose can cause fluidelectrolyte balance disorders, especially in potassium and sodium ions. $\mathrm{K}+$ and $\mathrm{Na}+$ ions if excreted beyond normal limits can cause disturbances in the body in the form of hyponatremia and hypokalemia (Imelda and Andana, 2006). Disorders caused by ion deficiency can cause damage to the kidneys (Singh et al., 2003).

One of the kidney damage is glomerular capillaries disorder thus that it will decrease the glomerular filtration rate and the permeability of the glomerular capillaries will increase. Increased glomerular permeability will cause substances to enter without being filtered and these substances will collect in the space 
between the glomerulus and Bowman's capsule. The filtrate will fill the space, causing the glomerulus to become compressed and shrink, which is called glomerular atrophy. Bowman's capsule will be pushed by the filtrate so that it will expand (Macfarlane et al., 2000). Glomerular atrophy is characterized by the enlargement of Bowman's space, so that the space between the glomerulus and Bowman's capsule widens. Reduced cell number or cell size is also a sign of glomerular atrophy, so that the size of the glomerular tissue shrinks (Spector and Spector, 1993).

Therefore, this study was conducted to determine the effect of salak seed extract on urine volume, levels of urea, creatinine and kidney histopathological structure in Rattus norvegicus.

\section{MATERIALS AND METHODS}

This research was carried out at the Botany and Zoology Laboratory, Mathematics and Natural Science Faculty, University of Jember from February to April 2021.

\section{Preparation of Salac Seed Extract}

Salak fruit is obtained from the Kolpajung Market in Pamekasan area, then the pulp cleaned and separated the seeds. Salak seeds were air-dried and roasted at $50^{\circ} \mathrm{C}$ for \pm 2 days to dry, then ground and sieved (60 mesh) to produce powder. Salak seed extract was made by maceration method, using $70 \%$ ethanol with a ratio of $1: 10$, for $2 \times 24$ hours. The maceration results were evaporated using a rotary evaporator at a temperature of $70^{\circ} \mathrm{C}$ and a speed of $50 \mathrm{rpm}$, then evaporated using a waterbath at a temperature of $70^{\circ} \mathrm{C}$ for \pm 8 hours to get paste of salak seeds.

\section{Fitochemical assay of Salak Seed Extract}

\section{A. Flavanoid Test}

As much as 0.1 gram of salak seed extract mix with methanol until submerged and then heated. The filtrate was added with concentrated $\mathrm{H}_{2} \mathrm{SO}_{4}$. The formation of red color indicates flavonoids.

\section{B. Alkaloid Test}

As much as 0.1 grams of salak seed extract mix with $1 \mathrm{ml}$ of chloroform and 5 $\mathrm{ml}$ of $10 \%$ ammonia, then heated and filtered. The filtrate was added with concentrated $\mathrm{H}_{2} \mathrm{SO}_{4}$. The formation of brownish red color indicates alkaloids.

\section{Tanin Test}

A total of 0.1 grams of salak seed extract mix with $5 \mathrm{ml}$ of distilled water then heated to boiling for 5 minutes and filtered. After that, the filtrate was added with 5 drops of $\mathrm{FeCl} 31 \%(\mathrm{w} / \mathrm{v})$. The presence of tannin is indicated by the formation of dark blue or greenish black colour.

\section{Animal and Treatment}

The animals used in the study were male rats (Rattus norvegicus) Wistar strain aged 2 months and body weight $200 \mathrm{~g}$. Rats were obtained from Malang and adapted in a metabolic cage for 7 days, and given feed in the form of pellets and drinking aquadest on an ad libitum basis. Rats were divided into 4 treatment groups respectively negative control (distilled water), extract of salak seeds at a dose of $0.28 \mathrm{~g} / \mathrm{kg}$ body weight, $0.56 \mathrm{~g} / \mathrm{kg}$ body weight and $1.12 \mathrm{~g} / \mathrm{kg}$ body weight.

The treatment of test animals in this study using the Lipschitz method, before the treatment of rats fasted for \pm 18 hours. After that the rats were given a loading dose of 1 $\mathrm{ml}$ of warm aquadest and left for 30 minutes. Furthermore, rats were treated orally according to the dosage using gastric sonde for 7 days (Wientarsih et al, 2012). On the first day after giving the treatment, the rats were not given food and drink, then a diuretic test was performed and the total urine volume was measured for 6 hours. Mice were killed on day 8 by being anesthetized using $0.1 \mathrm{ml}$ of Ketamine and $0.02 \mathrm{ml}$ of Xyla per mouse, then dissected. Furthermore, the kidney organs are taken to make histological preparations with the paraffin block method and Hematoxylin and Eosin staining. 
Creatinine, Urea and Urine Volume Measurement

Measurement of creatinine and urea is carried out before and after administration of salak seed extract. Rats were placed in a metabolic cage equipped with a urine container, the urine obtained was measured with a measuring cup. Measurement of total urine volume for 6 hours after the last treatment.

\section{Preparations and Observing of Kidney Histology}

Kidney organs is carried out for the preparation of kidney histology. The method used is the paraffin method and the staining of HE (Haemotoxylin-Eosin). Paraffin methods include fixation, dehydration, clearing, infiltration, embedding, sectioning, affixing, staining, and mounting (Suntoro, 1983).

Measurement of the diameter of the kidney glomerulus was carried out using a 400x magnification microscope.

\section{Statistical Analysis}

Data on urine volume and diameter of the kidney glomerulus obtained from the results of the study were analyzed using the One Way ANOVA test with a confidence level of $95 \%$ or $\alpha=0.05$ followed by the Duncan Multiple Range Test (DMRT) to see significant differences between dose treatment groups.

\section{RESULT AND DISCUSSION}

Chemical content analysis of salak seed extract in this study using a qualitative phytochemical screening test to detect the presence of flavonoids, alkaloids and tannins. The results of the chemical assay of the salak seed extract can be seen in Table 1 .

Table 1. Qualitative chemical compounds in salak seed extract

\begin{tabular}{cc}
\hline $\begin{array}{c}\text { Secondary } \\
\text { metabolites }\end{array}$ & Results \\
\hline Flavonoid & Positive \\
Alkaloid & Positive \\
Tannin & Positive \\
\hline
\end{tabular}

Based on Table 1, salak seed extract contains flavonoids (positive) which are marked by the formation of red color, alkaloids (positive) which are marked by the formation brownish red color and contains tannins (positive) characterized by the formation of greenish black color. This is similar with the research of Latuconsina et al. (2014) that salak seed contain flavonoid compounds, alkaloids and tannins. Flavonoids are potent antioxidants, and diuretic (Nessa et al., 2013).

\section{Salak Seed Extract Diuretic Activity Test}

Diuretic test is done by measuring the total urine volume of male white rats (Rattus norvegicus) for 6 hours. The observation of total urine volume for 6 hours can be seen in table 2 .

Table 2 Total urine volume of white rats after administration of salak seed extract.

\begin{tabular}{cccc}
\hline $\begin{array}{c}\text { Treatme } \\
\text { nt }\end{array}$ & $\begin{array}{c}\text { Urine } \\
\text { Volume } \\
(\mathbf{m l}) \\
(\mathbf{M e a n} \pm \\
\text { SD) }\end{array}$ & $\begin{array}{c}\text { Creatin } \\
\mathbf{e} \\
(\mathbf{m g} / \mathbf{d L}) \\
(\mathbf{M e a n} \pm \\
\mathbf{S D})\end{array}$ & $\begin{array}{c}\text { Urea } \\
(\mathbf{m g} / \mathbf{d L} \\
(\mathbf{M e a n} \\
\mathbf{( S D})\end{array}$ \\
\hline Negative & $2,68^{\mathrm{a}} \pm$ & $1,68 \pm$ & $36,47 \pm$ \\
Control & 1,07 & 0,31 & 12,59 \\
$0.28 \mathrm{~g} / \mathrm{kgb}$ & $3,43^{\mathrm{a}} \pm$ & $1,66 \pm$ & $31,77 \pm$ \\
$\mathrm{b}$ & 0,90 & 0,20 & 12,62 \\
$0.56 \mathrm{~g} / \mathrm{kgb}$ & $3,68^{\mathrm{a}} \pm$ & $1,59 \pm$ & $30,12 \pm$ \\
$\mathrm{b}$ & 1,08 & 0,27 & 7,32 \\
$1.12 \mathrm{~g} / \mathrm{kgb}$ & $5,00^{\mathrm{b}} \pm$ & $1,38 \pm$ & $28,91 \pm$ \\
$\mathrm{b}$ & 1,09 & 0,32 & 13,07 \\
\hline
\end{tabular}

Note: numbers followed by the same letters in the same column show no significant difference in the DMRT test with a significance level $\alpha=0.05$

Based on the ANOVA test on the urine volume, $\mathrm{p}$ value is $0.008<0.05$, while the creatinine and urea levels showed $p=0.266$ $>0.005$ and $\mathrm{p}=0.695>0.05$. These results indicate that administration of salak seed extract has a diuretic effect by increasing urine volume in male rats (Rattus norvegicus) but didn't reduce creatine and urea levels. 
The Duncan's test result on urine volume showed that there was a significant difference between the negative control the treatment group at a dose of $1.12 \mathrm{~g} / \mathrm{kgbb}$. The highest increase in urine volume occurred at a dose of $1.12 \mathrm{~g} / \mathrm{kgbb}$. This is presumably due to the presence of flavonoid compounds, alkaloids and tannins in salak seeds with evidence of positive qualitative analysis results (table 1).

According to Geurin and Reveillere (1989), flavonoids act as diuretic compounds work by inhibiting the reabsorption of $\mathrm{Na}+\mathrm{K}+$ and $\mathrm{Cl}-$ so that there is an increase in electrolytes in the tubules and more urine volume is produced. Alkaloids also act as diuretic compounds that work synergistically with flavonoids by increasing the excretion of $\mathrm{Na}+$ and $\mathrm{Cl}$ - in the kidney tubules (Nessa et al., 2013). While tannins are phenolic secondary metabolites because they are derivatives of flavonoids, so that the way these compounds work is the same as flavonoids, namely inhibiting the reabsorption of $\mathrm{Na}+$ and Clions and the amount of urine produced is greater (Syafitri et al., 2014). Based on Table 2 , the increasing of concentration dose given, the urine volume was increased. This result was similiar to Latuconsina's et al research (2014).

\section{Histological Structure of Rat Kidney After Giving Salak Seed Extract}

Histological structure of the rat's kidney (Rattus norvegicus) after the treatment of salak seed extract was observed by measuring diameter of glomerulus can be seen in table 3.

Table 3 The average of glomerulus diameter Rattus norvegicus after the treatment of salak seed extract.

\begin{tabular}{cc}
\hline Treatment & $\begin{array}{c}\text { Glomerulus } \\
\text { diameter }(\boldsymbol{\mu m}) \\
(\text { Mean } \pm \text { SD) }\end{array}$ \\
\hline Negative Control & $81,35 \pm 1,51$ \\
$0.28 \mathrm{~g} / \mathrm{kgbb}$ & $80,47 \pm 2,82$ \\
$0.56 \mathrm{~g} / \mathrm{kgbb}$ & $81,60 \pm 4,07$ \\
$1.12 \mathrm{~g} / \mathrm{kgbb}$ & $82,17 \pm 4,24$ \\
\hline
\end{tabular}

Based on the Anova test, $\mathrm{p}$ value was 0.647 $(p>0,05)$. This is indicated there was no significantly difference between negative control and treatment group. These results indicate that the treatment of salak seed extract didn't damage the kidneys or couldn't make kidney atrophy, is characterized by didn't changes of the glomerular diameter. The atrophy glomerular is characterized by the glomerular become shrink and enlargement of Bowman's space (Spector and Spector, 1993).

The natural diuretics i.e salak seed extract didn't reduce the glomerular filtration rate. Wientarsih et al. (2014), reported that flavonoid can increase the glomerular filtration rate, effect to resulting in more urine being excreted. According to Suharyadi et al. (2007), flavonoid as antiinflammatory, it can reduce kidney damage (Suharyadi et al., 2007). A high glomerular filtration rate could be increase production of urine volume and inhibit swelling of the kidney glomerular. Kataoka et al. (2011), stated the glomerular has a diameter of less than $221 \mathrm{~m}$ is a normal or has not to be damaged.

Long term consumed of synthetic diuretics and exceed the recommended dose can caused fluid-electrolyte balance disorders, particularly in potassium and sodium ions. $\mathrm{K}+$ and $\mathrm{Na}+$ ions if excreted beyond normal limits can cause disturbances in the body i.e hyponatremia and hypokalemia (Imelda and Andana, 2006). Disorders caused by ion deficiency can cause kidney damage (Singh et al., 2003).

The kidney glomerular histological after treatment of salak seed extraction can be seen figure 4.1 .

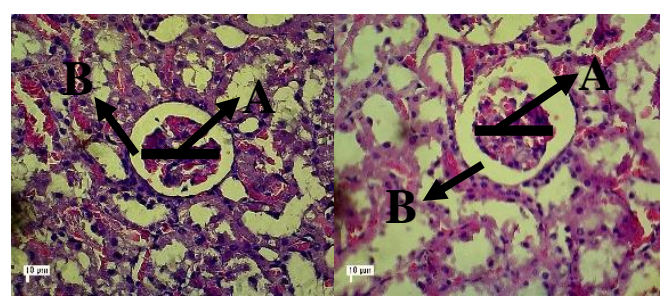

(a)

(b) 


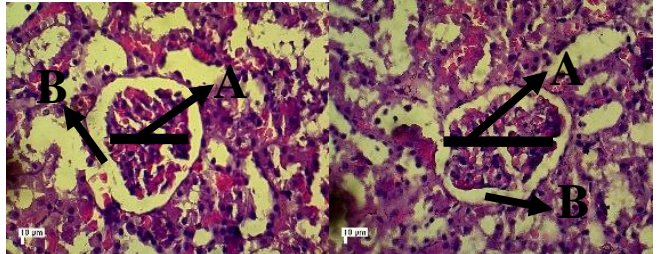

(c)

(d)

(a) Negative control (b) salak seed extract dose $0.28 \mathrm{~g} / \mathrm{kgbb}$; (c) salak seed extract dose $0.56 \mathrm{~g} / \mathrm{kgbb}$; (d) salak seed extract dose $1.12 \mathrm{~g} / \mathrm{kgbb}$; A: Glomerular; B: Bowman space

Picture 4.1 Glomerular histological after treatment of salak seed extract $(400 \mathrm{x}$ magnification)

\section{CONCLUSION}

Based on the results of this study, it can be concluded that the treatment of salak seed extract has a diuretic effect by increasing urine volume in male rats (Rattus norvegicus) but didn't reduce creatine and urea levels. The highest increase in urine volume occurred at a dose of $1.12 \mathrm{~g} / \mathrm{kgbb}$. The all treatment doses of salak seed extract had no effect on the kidney histopathological structure, i.e it was not effect on glomerular diameter or did not cause atrophy of kidney glomerular. The atrophy glomerular is characterized by the glomerular become shrink and enlargement of Bowman's space.

\section{REFERENCES}

Achmad, S.A. 1986. Buku Materi Pokok Kimia Organik Bahan Alam. Jakarta: Penerbit Karunika Jakarta, Universitas Terbuka.

Adha, A. C. 2009. Pengaruh pemberian ekstrak etanol daun alpukat (Persea americana Mill.) terhadap aktivitas diuretik tikus putih jantan SpragueDawley. Skripsi. Fakultas Kedokteran Hewan. Bogor: Institut Pertanian Bogor.

Geurin, J.C., dan H. P. Reveillere. (1989). Orthosiphone stamineus as a potent source of methylripario chromene. $A, J$. Nat. Prod. 52: 171-173.

Guyton, A.C. \& Hall, J.E. 2006. Buku Ajar Fisiologi Kedokteran. Ed ke-11.
Jakarta: Penerbit Buku Kedokteran. EGC.

Imelda E. dan E. P. Andana. 2006. Perbandingan efek diuretik serta kadar natrium dan kalium darah antara pemberian ekstrak etanol daun tempuyung (Sonchus arvensis Linn) dengan furosemid. Jurnal Sains dan Teknologi Farmasi. 11:76-80.

Jouad, H., M. A. Lacaille-Dubois, B. Lyoussi, dan M. Eddouks. 2001. Effects of the flavonoids extracted from Spergularia purpurea Pers. on arterial blood pressure and renal function in normal and hypertensive rats. Journal of Ethnopharmacology. 76(2):159-63.

Latuconsina, N.H., Fatimawati \& Citraningtyas, G. 2014. Uji Efektivitas Diuretik Ekstak Etanol Biji Salak (Salacca zalacca (gaert.)Voss) Pada Tikus Putih Jantan Galur Wistar (Rattus norvegicus). Jurnal Ilmiah Farmasi Unsrat Vol. 3 No. 3 : 176-181.

Macfarlane PS, R. R, dan R. C. 2000. Pathology Ilustrated. Ed Ke-5. London: Churchill Livingstone.

Nessa, H. Arifin, dan H. Muchtar. 2013. Efek diuretik dan daya larut batu ginjal dari ekstrak etanol rambut jagung (Zea mays L.). Prosiding Seminar Nasional Perkembangan Terkini Sains Farmasi dan Klinik III. Padang : Fakultas Farmasi, Universitas Andalas.

Novita. 2014. Uji Efektivitas Diuretik Ekstak Etanol Biji Salak (Salacca zalacca (gaert).Voss) Pada Tikus Putih Jantan Galur Wistar (Rattus norvegicus). Jurnal Ilmiah Farmasi. FMIPA Universitas Samratulangi Manado.

Nurdiniyah, Nazaruddin, Sugito, M. N. Salim, Y. Fahrima, dan S Aisyah. 2015. Pengaruh pemberian ekstrak kulit batang jaloh terhadap gambaran mikroskopis ginjal tikus putih (Rattus novergicus) yang diinfeksi Trypanosoma evansi. Jurnal Medika Veterinaria. 9(2).

Saravanan, C., Shanta, K. S., Anandan, R., Narayanaswamy, V. B., Varunraj, S. 2010. Anti-Infalamatory and Diuretic Effect of Plant Extract of 
Pseudarthria viscida (L) Weight \& Arn. IJRAP. 1(2) 506-509.

Singh, N.P., A. Ganguli, dan A. Prakash. 2003. Drug-induced kidney disease. JAPI. 51:970-980.

Siswandono. 2016. Kimia Medisinal, Jilid I, Edisi II, 249-261. Airlangga University Press, Surabaya.

Spector, W. G. dan T. W. Spector. 1993. Pengantar Patologi Umum. Ed Ke-3. Yogyakarta: Gadjah Mada University Press.

Suharyadi A., Sukohar A., dan Muhartono. 2007. The effects of soursop leaf ethanol extract on renal histopathological analysis of DMBA induced. Jurnal Kedokteran. ISSN 2337-3776.

Suntoro, H. 1983. Metode Pewarnaan. Jakarta: Bhratara Karya Aksara.

Syafitri, N. E., M. Bintang, dan S. Falah. 2014. Kandungan fitokimia, total fenol, dan total flavonoid ekstrak buah harendong (Melastoma affine D. Don). Current Biochemistry 1(3): 105-115.

Tanu, I. 2009. Farmakologi dan Terapi. Edisi 5 (Cetak Ulang dengan Perbaikan). Jakarta: Balai Penerbit FKUI.

Wientarsih, I., R. Madyastuti., B. Febran., dan D. Firnanda. 2012. Gambaran Serum Ureum dan Kreatinin Pada Tikus Putih Yang Diberi Fraksi Etil Asetat Daun Alpukat. Jurnal Veteriner. 13(1):57-62.

Wientarsih, I., E. Harlina, R. M. Purwono, dan I. T. H. Utami. 2014. Aktivitas ekstrak etanol daun alpukat terhadap zat nefrotoksik ginjal tikus. Jurnal Veteriner. 15(2):246-251. 